\title{
Biological control of rose powdery mildew (Podosphaera pannosa (Wallr.: Fr.) de Bary
}

\author{
VIJAY KUMAR*, SUNITA CHANDEL AND NEELAM KUMARI
}

Department of Plant Pathology, Dr. Y.S. Parmar University of Horticulture and Forestry, Nauni, SOLAN (H.P.) INDIA

\section{ARITCLE INFO}

Received : 14.05 .2016

Accepted : 24.09.2016

\section{KEY WORDS :}

Antagonists, Biological control, Bioproducts, Botanicals, Podosphaera pannosa, Rose
*Corresponding author:

Email : vnarwal777@yahoo.com; vnarwa1257@gmail.com

\begin{abstract}
Powdery mildew, caused by Podosphaera pannosa (Wallr.: Fr.) de Bary (Syn. Sphaerotheca pannosa var rosae (Wallr.: Ex Fr.) Lev.), is one of the most important fungal diseases in roses. These are obligate parasites and considered as one of the most distributed and destructive groups of plant pathogens. The symptoms appear on leaves, shoots, buds, thorns, peduncles and flowers as powdery, whitish growth (mycelium, conidiophores and spores) of the mildew fungus. Plants can be severely stunted if they are heavily infected early in the growing season. The disease has been managed mainly by chemical fungicides but increasing public concern over the use of fungicides has made the development of biological control for powdery mildew highly desirable. Recent reports have highlighted the potential of biological control as an alternative strategy for disease management. Several biological control methods such as use of microbial antagonists (fungi, bacterial, yeast and yeast like organisms), botanicals and bioproducts have been found effective against rose powdery mildew fungi. The main objective of this review paper is to summarize the data on the microbial antagonists, bioproducts (anhydrous milk products, oils and compost extracts) and botanicals which have been reported effective for the better management of this plant pathogen.
\end{abstract}

How to view point the article : Kumar, Vijay, Chandel, Sunita and Kumari, Neelam (2016). Biological control of rose powdery mildew (Podosphaera pannosa (Wallr.: Fr.) de Bary. Internat. J. Plant Protec., 9(2) : 639-643, DOI : 10.15740/HAS/IJPP/9.2/639-643. 